\title{
Expression of Genes Affecting Skin Coloration and Sugar Accumulation in Apple Fruits at Ripening Stages in High Temperatures
}

\author{
Seon Ae Kim1, Soon Young Ahn1, Hyun Hee Han², In Chang Son², Hae Keun Yun1* \\ ${ }^{1}$ Department of Horticulture and Life Science, Yeungnam University, Gyeongsan, South Korea \\ ${ }^{2}$ National Institute of Horticultural \& Herbal Science, Wanju, South Korea \\ Email: ${ }^{*}$ haekeun@ynu.ac.kr
}

Received 5 July 2015; accepted 20 August 2015; published 25 August 2015

\begin{abstract}
High temperature is one of the most important environmental factors that affect the successful cultivation of apple (Malus $\times$ domestica Borkh). The expression of genes related with anthocyanin synthesis and sugar accumulation by high temperature treatment was investigated in the fruits of "Fuji" apple at different developmental stages in different temperature conditions through realtime PCR. In the initial ripening stages in fruits, there was high expression of genes associated with fruit ripening, flavonoid compound accumulation, and coloration in high temperatures. Expression of phenylalanine ammonia-lyase, chalcone synthase, flavone 3-hydrogenase, and malate dehydrogenase genes increased gradually in initial ripening stages, while sharply reduced at $24 \mathrm{hr}$ after treatment. In addition, there was no significant difference in the expression of all temperature treatments in late ripening stages. In the further work, investigation of expression levels of various genes could be conducted in the level of transcriptomes from fruits at the early stages to get meaningful information of ripening metabolism in apples in high temperatures.
\end{abstract}

\section{Keywords}

Anthocyanin, Apple, High Temperature, Skin Coloration, Sugar Content

\section{Introduction}

The domesticated apple (Malus $\times$ domestica Borkh.) is one of the main fruits of temperate regions of the world [1]. Biotic or abiotic stresses result in significantly reduced productivity through adverse growth effect in plants. In apple, coloration of skin and total soluble solids are important factors in fruit quality, and are influenced by temperature conditions in their growing season [2] [3]. Temperature is one of the major factors on anthocyanin synthesis in skins of a diverse range of fruits such as apple [4], grape [5], and orange [6]. In apple, accumulation

"Corresponding author.

How to cite this paper: Kim, S.A., Ahn, S.Y., Han, H.H., Son, I.C. and Yun, H.K. (2015) Expression of Genes Affecting Skin Coloration and Sugar Accumulation in Apple Fruits at Ripening Stages in High Temperatures. World Journal of Engineering and Technology, 3, 7-12. http://dx.doi.org/10.4236/wjet.2015.33B002 
of cyaniding and UDP-sugars was inhibited by high temperatures, while accumulation of anthocyanin was rapidly inhibited by cold temperatures to cause fluctuations in skin color [7] [8].

Among characters affecting apple fruit quality, the red coloration of the fruit skin is of major importance and significantly determines the market value of the produce. Although the pigments determining fruit color are various dependent on fruits, the amount and composition of anthocyanins, a class of flavonoids, are the major determinants in reddening the skin of apple fruits [9] [10]. Although poor coloration occasionally happened even in the temperate zones with climate condition favorable for fruits growing and ripening, coloration of skin was also reported to be inhibited or delayed at high temperature [11]. Several studies reported that accumulation of pigment in fruit skins resulted from expression level of anthocyanin biosynthetic genes during ripening of apples [9] [12].

Recently, the rising temperatures due to urbanization and industrialization resulted in lots of problems such as growth retardation, reduced sugar content, poor coloring fruit shape, and shortening the shelf life of the fruit, and made a negative effect on the quality apple production and farm income [13]. Continuous high temperature by climate shift and global warming causes the poor ripening fruits. In this study, therefore, we were to examine the expression level of genes related in anthocyanin synthesis and sugar accumulation including $\beta$-amylase (BMY), phenylalanine ammonia-lyase (PAL), and flavanone 3-hydroxylase (F3H), and to determine the point to collect samples appropriate for transcriptome analysis of apple fruits as affected by high temperatures.

\section{Materials and Methods}

\subsection{Plant Materials and Temperature Treatment}

Healthy "Fuji" apple was harvested at 3 different stages at the experimental orchard, after which they were placed in separate growth chambers (Ilshin Tech., Daejeon, South Korea) equipped with temperature controller and then maintained in $25^{\circ} \mathrm{C}, 30^{\circ} \mathrm{C}$, and $35^{\circ} \mathrm{C}$. Fruits were collected at $0,6,12,24,48 \mathrm{~h}$ after temperature treatment. The fruits were frozen immediately in liquid nitrogen and stored at $-80^{\circ} \mathrm{C}$ until use for RNA extraction.

\subsection{RNA Isolation and Real-Time PCR}

Total RNA was extracted from fruits using a modified version of the method described by [14]. The quality of the total RNA was examined with the Nano Drop spectrophotometer (ND-1000, Technologies Inc., USA). Total RNA (500 ng) was used to synthesize cDNA using a GoScriptTM Reverse Transcription System (Promega, Madison, WI, USA). Reactions were run on the C1000TM Thermal Cycler (BioRad, Hercules, CA, USA) using SYBR Premix Ex (Takara Bio Inc., Osaka, Japan) as the fluorescent dye. Real-time PCR was performed under the following conditions: $95^{\circ} \mathrm{C}$ for $30 \mathrm{~s}$, followed by 40 cycles at $95^{\circ} \mathrm{C}$ for 5 sand $60^{\circ} \mathrm{C}$ for $30 \mathrm{~s}$. Transcripts levels of each genes were normalized using standard-curve method and calculated against the apple act in gene (XM_008362405.1) as an internal control, after which melting curves of the amplified products were recorded. Untreated apples (at time zero) were tested as the reference sample. For each gene, the reference sample was defined as the $1 \mathrm{x}$ expression level, and the results were expressed as the fold increase in mRNA over the reference sample. The gene specific primers shown in Table 1 were designed using the Primer 3 (http://frodo.wi.mit.edu/primer3) for real-time PCR.

\section{Results and Discussion}

To analyze the changes of expression level of genes related to anthocyanin synthesis and sugar accumulation during the ripening of apples were evaluated following different high temperatures, the expression of genes such as $\beta$-amylase (BMY), polygalacturonase (PG), phenylalanine ammonia-lyase (PAL), chalcone synthesis (CHS), flavanone 3-hydroxylase (F3H), and malate dehydrogenase (MDH) was investigated with each specific primer in "Fuji" apple fruits with three different ripening stages using real-time PCR. As apple fruits ripened, expression of BMY genes was up regulated in both initial and late ripening stages, whereas it was rapidly down regulated at $6 \mathrm{hr}$ after treatment in middle ripening stage (Figure 1).

PG gene expression was inhibited in all tested stages at $35^{\circ} \mathrm{C}$, and was higher in the initial ripening stage than in the late ripening stages of in apple fruits. Expressions of PAL, CHS, F3H, and MDH genes increased gradually in initial ripening stages, while were sharply reduced at $24 \mathrm{hr}$ after treatment (Figure 2).

In middle ripening stages, $\mathrm{F} 3 \mathrm{H}$ and $\mathrm{MDH}$ were rapidly inhibited at $6 \mathrm{hr}$, and then slightly recovered in gene 
Table 1. NCBI gene accession numbers and sequences of gene primers used for quantitative real-time PCR analysis.

\begin{tabular}{|c|c|c|}
\hline Gene & Accession No. & Primer sequences \\
\hline \multirow[t]{2}{*}{ Actin } & XM_008362405.1 & 5'-TTTAGCATCCСТCAGCACСТTC-3' \\
\hline & & 5'-TACTCTGCСТTTGCAATCCACA-3' \\
\hline \multirow[t]{2}{*}{$\beta$-amylase (BMY) } & XM_008393061.1 & 5'-CAGGCTGTGATGTCGTTTCATC-3’ \\
\hline & & 5'-CACAACCCATTTGGGTAAAGGA-3' \\
\hline \multirow[t]{2}{*}{ Polygalacturonase (PG) } & NM_001293928.1 & 5'-CAACACAATCATCGGTGGGATA-3' \\
\hline & & 5'-CACAAATGCCTGTGTGTCATCA-3' \\
\hline \multirow[t]{2}{*}{ Phenylalanine ammonia-lyase(PAL) } & X68126.1 & 5'-GTTGAGAGTGCAAGGAGTGCAA-3' \\
\hline & & 5'-TCTCCCCGGTTAGGTACTCTCC-3' \\
\hline \multirow[t]{2}{*}{ Chalcone synthesis (CHS) } & AY786996.1 & 5'-AGGACATGGTGGTTGTGGAAGT-3' \\
\hline & & 5'-AGACCAAGTGGGTGATTTTGGA-3' \\
\hline \multirow[t]{2}{*}{ Flavanone 3-hydroxylase (F3H) } & AF117270.1 & 5'-TTGTAGCGGCTTGTGAAGACTG-3' \\
\hline & & 5'-ATCAАCСССАTGGTCAАCАATC-3' \\
\hline \multirow[t]{2}{*}{ Malate dehydrogenase (MDH) } & XM_008364115.1 & 5’-CTTGGGTTTCCATGGGTGTTTA-3’ \\
\hline & & 5'-ATGTTGGCAAGTGACTGGGAAT-3' \\
\hline
\end{tabular}
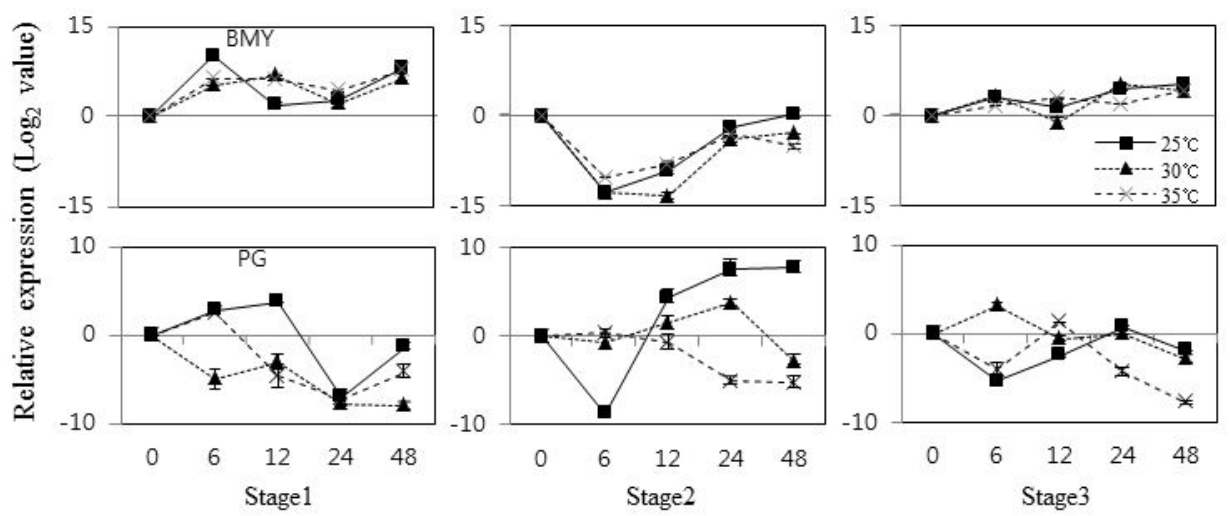

Figure 1. Expression of beta-amylase (BMY) and polygalacturonase (PG) genes by different temperatures in the fruits of apple. The error bars represent the standard error of the means of three replicates. Stage 1: initial ripening stage; Stage 2: middle ripening stage; Stage 3: late ripening stage.

expressions. In addition, all tested genes showed no significant different level in their expression at three different temperatures in late ripening stages. The expression level of all genes related with anthocyanin synthesis was lower especially at $35^{\circ} \mathrm{C}$ than $25^{\circ} \mathrm{C}-30^{\circ} \mathrm{C}$ in the middle ripening stages, which was similar to the results from sugar accumulation-related gene analysis in apple fruits.

At $30^{\circ} \mathrm{C}$, the photosynthetic efficiency and growth of shoots and fruits begin to decrease in fruit development stages (June-August) in UK. Moreover, at $35^{\circ} \mathrm{C}$, photosynthetic rate are rapid decreases because of increased respiratory cost [15]. The content of total soluble solids showed the tendency to increase at lower temperature $\left(20^{\circ} \mathrm{C}-25^{\circ} \mathrm{C}\right)$ compared to $30^{\circ} \mathrm{C}$ in "Fuji" apple fruits in growth stage [16]. Among sugars, such as sucrose, fructose, and glucose, sucrose is predominant for cellular growth in the young fruit of apple. Sorbitol is the major substrate for fructose accumulation, and also plays an important role in the metabolism of sugar accumulation during development [17]. PG was encoded by relatively large gene families and involvement in apple fruit ripening [18]. It was reported that PG may occur in differential temperature-dependent regulation of ethyleneresponsive genes, and regulated by the action of various cell wall enzymes in apple [19]. In this study, expression of BMY and PG genes related with sugar synthesis was inhibited at $35^{\circ} \mathrm{C}$ compared to $25^{\circ} \mathrm{C}-30^{\circ} \mathrm{C}$ in the 

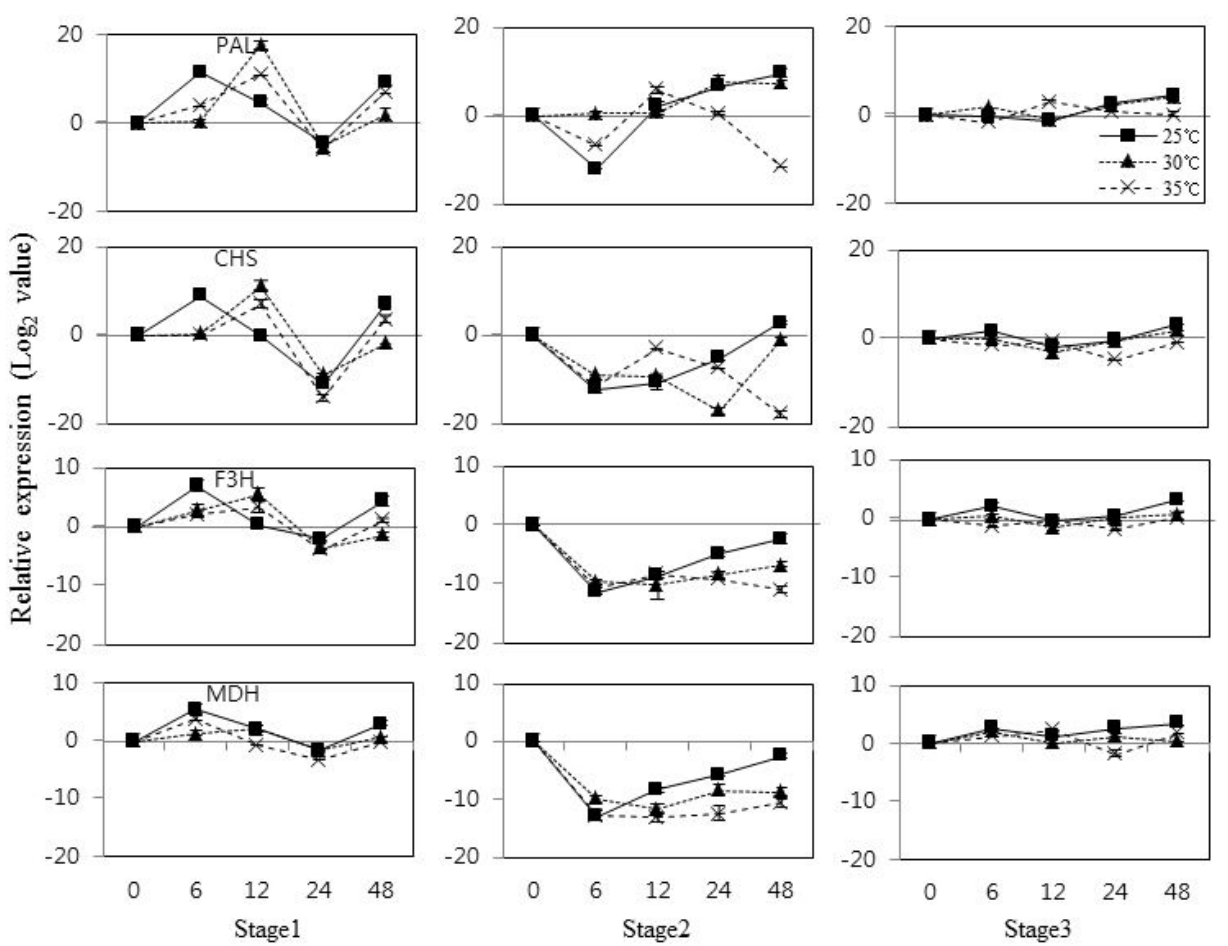

Figure 2. Expression of phenylalanine ammonia lyase (PAL), chalcone synthase (CHS), flavone 3-hydrogenase $(\mathrm{F} 3 \mathrm{H})$, and malate dehydrogenase $(\mathrm{MDH})$ genes by different temperatures in the fruits of apple. The error bars represent the standard error of the means of three replicates. Stage 1: initial ripening stage; Stage 2: middle ripening stage; Stage 3: late ripening stage.

fruits at ripening stage. Many studies investigated induction and inhibition in the level of anthocyanin accumulation during fruit development in apple. The anthocyanin accumulation is regulated by environmental factors, such as temperature, light, nutrition, and genetic factors [10].

The anthocyanin biosynthesis genes were reported to be regulated in ripening grape berries (Vitisvinifera L.) [20]. It was reported that anthocyanin content and PAL activity were effective to coloration at $15^{\circ} \mathrm{C}-20^{\circ} \mathrm{C}$ in apple fruits [21] [22]. Expression of anthocyanin biosynthetic genes, including MdCHS, MdF3H, dihydroflavonol 4-reductase reductase (pDFR), anthocyanin synthase (MdANS), and UDP galactose: flavonoid glucose transferase (pUFGluT), had a positive effect on anthocyanin accumulation for red coloration in apple and expression levels of genes were basically corresponded to the degree of anthocyanin concentrationin fruits [9]. Reference [23] showed that activity of PAL, chalconeisomerase (CHI), and UDP galactose: flavonoid3-O-galactosyltrans-ferase (UFGalT) in the fruit of "Splendour" apple was related with anthocyanin accumulation during the entire fruit ripening. However, [24] [25] demonstrated that CHS activity was not regulatory enzyme with anthocyanin biosynthesis in the skin of "Delicious" and "Ralls" apple fruits during the entire fruit development stage exposed to light. In addition, PAL activity wasn't correlated with anthocyanin accumulation in the skin of "Delicious" and flavonoid concentration was remained highly during the entire fruit development stage. In this study, expression of four genes such as PAL, CHS, F3H, and $\mathrm{MDH}$, which were related with fruit skin coloration, highly increased at the initial ripening stage, and decreased at the middle ripening stage in the three different temperatures. Interestingly, four genes were highly expressed at initial ripening stage (color break stage) compared to late ripening stage.

As temperatures are considered to rise in most parts of the world [26], the effect of climatic changes on yield and fruit quality attributes is one of the most topical issues in fruit crops [27]. Among various environmental factors involved in the mechanism of coloration of skin and sugar accumulation, temperature has been mainly focused for the research on fruit ripening [28] [29]. Because there are lots of factors which influence the ripening of apples, it is necessary to obtain useful information about the biochemical changes by high temperature by the use of systematic approaches including the transcriptome analysis from ripening fruits. Collectively, in this 
study we obtained important information which was useful to understand the high temperature response mechanism through comparative analysis of genes changed by high temperature stress in ripening stage of apple fruits in the molecular level. This result provides information about the most effective ripening stage of grape berry to show the changes in responses to high temperature for the further studies such as transcriptome analysis in the future.

\section{Acknowledgements}

This work was supported by a grant from the Agricultural R\&D (PJ010174), Rural Development Administration, South Korea.

\section{References}

[1] King, G.J. (1995) Progress of Apple Genetic Mapping in Europe. HortScience, 30, 749-749.

[2] Saure, M.C. (1990) External Control of Anthocyanin Formation in Apple. Scientia Horticulturae, 42, 181-218. http://dx.doi.org/10.1016/0304-4238(90)90082-p

[3] Tomana, T. and Yamada, H. (1988) Change in Sugar Composition during Maturation Stage of Apple Fruit Grown at Different Locations. Journal of the Japanese Society for Horticultural Science, 57, 178-183. http://dx.doi.org/10.2503/jjshs.57.178

[4] Ubi, B.E., Honda, C., Bessho, H., Kondo, S., Wada, M., Kobayashi, S. and Moriguchi, T. (2006) Expression Analysis of Anthocyanin Biosynthetic Genes in Apple Skin: Effect of UV-B and Temperature. Plant Science, 170, 571-578. http://dx.doi.org/10.1016/j.plantsci.2005.10.009

[5] Mori, K., Goto-Yamamoto, N., Kitayama, M. and Hashizume, K. (2007) Loss of Anthocyanins in Red-Wine Grape under high Temperatures. Journal of Experimental Botany, 58, 1935-1945. http://dx.doi.org/10.1093/jxb/erm055

[6] Lo Piero, A.R., Puglisi, I., Rapisarda, P. and Petrone, G. (2005) Anthocyanins Accumulation And related Gene Expression in Red Orange Fruit Induced by Low Temperature Storage. Journal of Agricultural and Food Chemistry, 53, 9083-9088. http://dx.doi.org/10.1021/jf051609s

[7] Ban, Y., Kondo, S., Ubi, B.E., Honda, C., Bessho, H. and Moriguchi, T. (2009) UDP-Sugar Biosynthetic Pathway: Contribution to Cyaniding 3-Galactoside Biosynthesis in Apple Skin. Planta, 230, 871-881. http://dx.doi.org/10.1007/s00425-009-0993-4

[8] Steyn, W., Holcroft, D., Wand, S. and Jacobs, G. (2005) Red Colour Development and Loss in Pears. Acta Horticulturae, 671, 79-85. http://dx.doi.org/10.17660/actahortic.2005.671.9

[9] Honda, C., Kotoda, N., Wada, M., Kondo, S., Kobayashi, S., Soejima, J., Zhang, Z., Tsuda, T. and Moriguchi, T. (2002) Anthocyanin Biosynthetic Genes Are Coordinately Expressed during Red Coloration in Apple Skin. Plant Physiology and Biochemistry, 40, 955-962. http://dx.doi.org/10.1016/S0981-9428(02)01454-7

[10] Lancaster, J.E. (1992) Regulation of Skin Color in Apples. Critical Reviews in Plant Sciences, 10, 487-502. http://dx.doi.org/10.1080/07352689209382324

[11] Lee, J.C., Tomana, T., Naoki, U. and Ikuo, K. (1979) Physiological Study on the Anthocyanin Development in Grape-I. Effect of Fruit Temperature on the Anthocyanin Development in "Kyoho" Grape. Korean Journal of Horticultural Scicence and Technology, 20, 55-65.

[12] Kondo, S., Hiraoka, K., Kobayashi, S., Honda, C. and Terahara, N. (2002) Changes in the Expression of Anthocyanin Biosynthetic Genes during Apple Development. Journal of the American Society for Horticultural Science, 127, 971-976.

[13] Hulme, M., Zhao, Z.C. and Jiang, T. (1994) Recent and Future Climate Change in East Asia. International Journal of Climatology, 14, 637-658. http://dx.doi.org/10.1002/joc.3370140604

[14] Chang, S., Puryear, J. and Cairney, J. (1993) A Simple and Efficient Method for Isolating RNA from Pine Trees. Plant Molecular Biology Reporter, 11, 113-116. http://dx.doi.org/10.1007/BF02670468

[15] Lakso, A.N. (1994) Apple. Handbook of Environmental Physiology of Fruit Crops, 1, 3-42.

[16] Yoon, C.G., Son, I.C. and Kim, D.I. (2010) Effects of Temperature during Growth Stage on Tree Growth and Fruit Quality in "Fuji”/M.9 Apples. Journal of the Korean Society of International Agriculture, 22, 143-147.

[17] Beruter, J. (1985) Sugar Accumulation and Changes in the Activities of Related Enzymes during Development of the Apple Fruit. Journal of Plant Physiology, 121, 331-341. http://dx.doi.org/10.1016/S0176-1617(85)80026-2

[18] Atkinson, R.G., Schroder, R., Hallett, I.C., Cohen, D. and MacRae, E.A. (2002) Overexpression of Polygalacturonase 
in Transgenic Apple Trees Leads to a Range of Novel Phenotypes Involving Changes in Cell Adhesion. Plant Physiology, 129, 122-133. http://dx.doi.org/10.1104/pp.010986

[19] Costa, F., P. Peace, C., Stella, S., Serra, S., Musacchi, S., Bazzani, M., Sansavini, S. and Van de Weg, W.E. (2002) QTL Dynamics for Fruit Firmness and Softening around an Ethylene-Dependent Polygalacturonase Gene in Apple Malus $\times$ domestica Borkh.). Journal of Experimental Botany, 61, 3029-3039.

[20] Boss, P.K., Davies, C. and Robinson, S.P. (1996) Analysis of the Expression of Anthocyanin Pathway Genes in Developing Vitis vinifera L. cv Shiraz Grape Berries and the Implications for Pathway Regulation. Plant Physiology, 111, 1059-1066.

[21] Noro, S., Ichinohe, H. and Obra, N. (1991) Effects of Controlled Air Temperature on Development of Anthocyanin, Sugar and Citramalic Acid during Maturation of the Apple Cultivar Starking Delicious. Bulletin of the Aomori Apple Experiment Station, 27, 111-123.

[22] Lee, H.C. (1999) Physiologycal and Ecological Factors Affecting Fruit Coloration and Color Enhancement in Malusdomestica Borkh. cv. "Fuji”. Ph. D. Thesis, Seoul National University, Seoul.

[23] Lister, C.E., Walker, J.E. and Lancaster, J.R.L. (1996) Developmental Changes in Enzymes of Flavonoid Biosynthesis in the Skins of Red and Green Apple Cultivars. Journal of the Science of Food and Agriculture, 71, 313-320. http://dx.doi.org/10.1002/(SICI)1097-0010(199607)71:3<313::AID-JSFA586>3.0.CO;2-N

[24] Ju, Z.G., Liu, C.L. and Yuan, Y.B. (1995) Activities of Chalcone Synthase and UDPGal: Flavonoid 3-O-glycosyltransferase in Relation to Anthocyanin Synthesis in Apple. Scientia Horticulturae, 63, 175-185. http://dx.doi.org/10.1016/0304-4238(95)00807-6

[25] Ju, Z.G., Yuan, Y.B., Liou, C.L. and Xin, S.H. (1995) Relationships among Phenylalanine Ammonia-Lyase Activity, Simple Phenol Concentrations and Anthocyanin Accumulation in Apple. Scientia Horticulturae, 61, 215-226. http://dx.doi.org/10.1016/0304-4238(94)00739-3

[26] Luedeling, E., Girvetz, E.H., Semenov, M.A. and Brown, P.H. (2011) Climate Change Affects Winter Chill for Temperate Fruit and Nut Trees. PLoS ONE, 6, e20155. http://dx.doi.org/10.1371/journal.pone.0020155

[27] Sugiura, S. and Yokozawa, M. (2004) Impact of Global Warming on Environment for Apple and Satsuma mandarin Production Estimated from Change of the Annual Mean Temperature. Journal of the Japanese Society for Horticultural Science, 73, 72-78. http://dx.doi.org/10.2503/jjshs.73.72

[28] Bergqvist, J., Dokoozlian, N. and Ebisuda, N. (2001) Sunlight Exposure and Temperature Effects on Berry Growth and Composition of Cabernet Sauvignon and Grenache in the Central San Joaquin Valley of California. American Journal of Enology and Viticulture, 52, 1-7.

[29] Azuma, A., Yakushiji, H., Koshita, Y. and Kobayashi, S. (2012) Flavonoid Biosynthesis-Related Genes in Grape Skin Are Differentially Regulated by Temperature and Light Conditions. Planta, 236, 1067-1080.

http://dx.doi.org/10.1007/s00425-012-1650-x 